Review Article

\title{
A Systematic Review on Technology-Supported Interventions to Improve Old-Age Social Wellbeing: Loneliness, Social Isolation, and Connectedness
}

\author{
Francisco Ibarra $\mathbb{D}^{1},{ }^{1,2}$ Marcos Baez $\mathbb{D}^{1},{ }^{1}$ Luca Cernuzzi $\mathbb{D},{ }^{2}$ and Fabio Casati $\mathbb{D}^{3}$ \\ ${ }^{1}$ Department of Information Engineering and Computer Science, University of Trento, Trento 38123, Italy \\ ${ }^{2}$ Department of Electronics and Informatics, Universidad Católica "Nuestra Señora de la Asunción", Asunción, \\ Tte. Lidio Cantaluppi y Guillermo Molinas, Paraguay \\ ${ }^{3}$ Tomsk Polytechnic University, Tomsk 634050, Russia
}

Correspondence should be addressed to Francisco Ibarra; fj.ibarracaceres@unitn.it

Received 18 September 2019; Revised 3 February 2020; Accepted 25 February 2020; Published 13 July 2020

Academic Editor: Kheng-Lim Goh

Copyright ( 2020 Francisco Ibarra et al. This is an open access article distributed under the Creative Commons Attribution License, which permits unrestricted use, distribution, and reproduction in any medium, provided the original work is properly cited.

\begin{abstract}
Background. This review studies technology-supported interventions to help older adults, living in situations of reduced mobility, overcome loneliness, and social isolation. The focus is on long-distance interactions, investigating the (i) challenges addressed and strategies applied; (ii) technology used in interventions; and (iii) social interactions enabled. Methods. We conducted a search on Elsevier's Scopus database for related work published until January 2020, focusing on (i) intervention studies supported mainly by technology-mediated communication, (ii) aiming at supported virtual social interactions between people, and (iii) evaluating the impact of loneliness or social isolation. Results. Of the 1178 papers screened, 25 met the inclusion criteria. Computer and Internet training was the dominant strategy, allowing access to communication technologies, while in recent years, we see more studies aiming to provide simple, easy-to-use technology. The technology used was mostly off-the-shelf, with fewer solutions tailored to older adults. Social interactions targeted mainly friends and family, and most interventions focused on more than one group of people. Discussion. All interventions reported positive results, suggesting feasibility. However, more research is needed on the topic (especially randomized controlled trials), as evidenced by the low number of interventions found. We recommend more rigorous methods, addressing human factors and reporting technology usage in future research.
\end{abstract}

\section{Introduction}

Social interactions significantly impact the quality of life of adults in general and older adults in particular. Health risks have been associated with the characteristics of each individual's social network, such as small size $[1,2]$, lack of diversity [3], infrequent contacts [4], and perceived social isolation [5]. Limited or poor social relationships have been shown to increase the risk of dementia by 60 percent [6]. Loneliness is a known risk factor for depression [7] and has been associated with increased risk of death and with functional decline [8]. A meta-analytic review of 70 studies [9] has shown that the likelihood of mortality increased by roughly 30 percent for reported loneliness, social isolation, and living alone, an effect comparable to those of smoking and obesity.

Several studies report that both loneliness-a subjective measure referring to the "unpleasant" lack of (quality of) social relationships [10] — and social isolation - an objective measure referring to the lack (absence or low number) of social relationships [10] - increase as we age. Studies on different geographical and cultural regions report on varying levels of loneliness and social isolation depending on the country and the scale used. Older adults experiencing loneliness have been reported in the $20 \%$ to $30 \%$ range in Europe [11], $19 \%$ to $32 \%$ in the United States [12, 13], and 
29.6\% and above in China [14]. These figures give us an indication of the extent of the barriers and challenges to social participation in older adults [15].

Indeed, several risk factors such as sensory incapacity and reduced mobility, as well as reductions in the quality and frequency of contact and requirements for long-term care or additional support, are associated with loneliness in old age [16]. Predictors of loneliness and isolation for older adults include health problems (such as chronic illness and cognitive decline), widowhood, and living far from relatives or alone [17]. Even when older adults engage in a conversation, interactions can be challenging. Williams and Nussbaum [18] reported on the challenges of intergenerational conversations, such as patronizing speech, painful disclosures, and underutilization of topical resources. In particular, lack of conversation topics can generate anxiety in intergenerational conversations [19]. These factors might affect older adults, but, more importantly, they are usually beyond the affected person's control [20].

Technological innovations, along with social and economic changes, have made interconnected devices a commonplace, thus creating opportunities for interaction $[21,22]$. Nonetheless, few reviews have focused on technology-supported interventions aiming at reducing loneliness and social isolation for older adults. Choi et al. [23] conducted a meta-analysis on computer and Internet training interventions, but did not cover newer devices. More recent reviews have analyzed assistive technologies and ICT interventions, but these have included interventions for general age-related problems, such as falls and medication management [24], or considered interventions that required colocated participation, such as playing video games [25].

In this systematic review, we focus instead on interventions enabling long-distance interactions through technology-mediated communication, targeting loneliness and social isolation in old age. Our objective is to identify the findings and limits of the knowledge acquired so far and to emphasize areas where further research is needed. More specifically, for the interventions analyzed, we investigate the following research questions:

$R Q 1$. What challenges of long-distance interactions are addressed and how?

RQ2. Which technologies are used by interventions and how?

$R Q 3$. What are the social interactions facilitated by interventions and with whom?

In the following, we discuss our investigation methods and results.

\section{Methods}

2.1. Search and Information Sources. We conducted a systematic review [26], reported here following the PRISMA statement guidelines [27], searching Elsevier's Scopus database for related work published in English until January, 2020. The search query was constructed using keywords for older adults (older adult OR older people OR senior OR elder OR ageing OR aging), the target problems (loneliness OR social isolation), means for interaction (technology OR Internet OR ICT OR IT OR computer OR tablet OR mobile OR smart phone), and focus on social (communication OR social interaction OR social network OR social networking OR social participation OR social cognition OR community).

2.2. Eligibility Criteria. We analyzed the title and abstract of each of the 1178 search results and verified whether the publication targeted older adults. For the purpose of this review, we adapted the definition of older adults by the WHO [28] and considered eligible studies reporting on participants aged 65 and older, or with a mean participant age above 65 years of age. In addition, we considered eligible papers that conformed to the following criteria:

(i) The work included an intervention (i.e., action taken to improve a situation)

(ii) The interactions with people were long-distance

(iii) The intervention supported mainly technologymediated communication

(iv) The impact on loneliness or social isolation was evaluated

Despite our focus on loneliness and social isolation, we considered social connectedness, the experience of belonging and relatedness among people, as a valid outcome because it is related to the (dis)satisfaction with contact quantity and quality [29].

2.3. Study Selection. After the identification and screening phases, 190 publications were left (see Figure 1). These publications were read fully and again discarded if not conforming to our inclusion criteria. An additional exclusion criterion for full paper screening was insufficient detail in reporting interventions, which would prevent a meaningful analysis. After a detailed inspection, 25 publications were left for full analysis.

2.4. Analysis and Synthesis. The review follows a narrative approach to the synthesis of results, given the heterogeneity of the studies included. In order to answer our research questions,

(i) On the challenges of long-distance interactions addressed by interventions (RQ1), we analyze intervention strategies and outcomes used to accomplish the study goals

(ii) On the technology used to support interventions (RQ2), we account for the technology and devices, as well as the use of the technology by older adults

(iii) On the social interactions enabled (RQ3), we describe the different contexts of interaction and the contacts reached by participants

Some authors were contacted to clarify the devices used in their interventions and the strategies that participants 


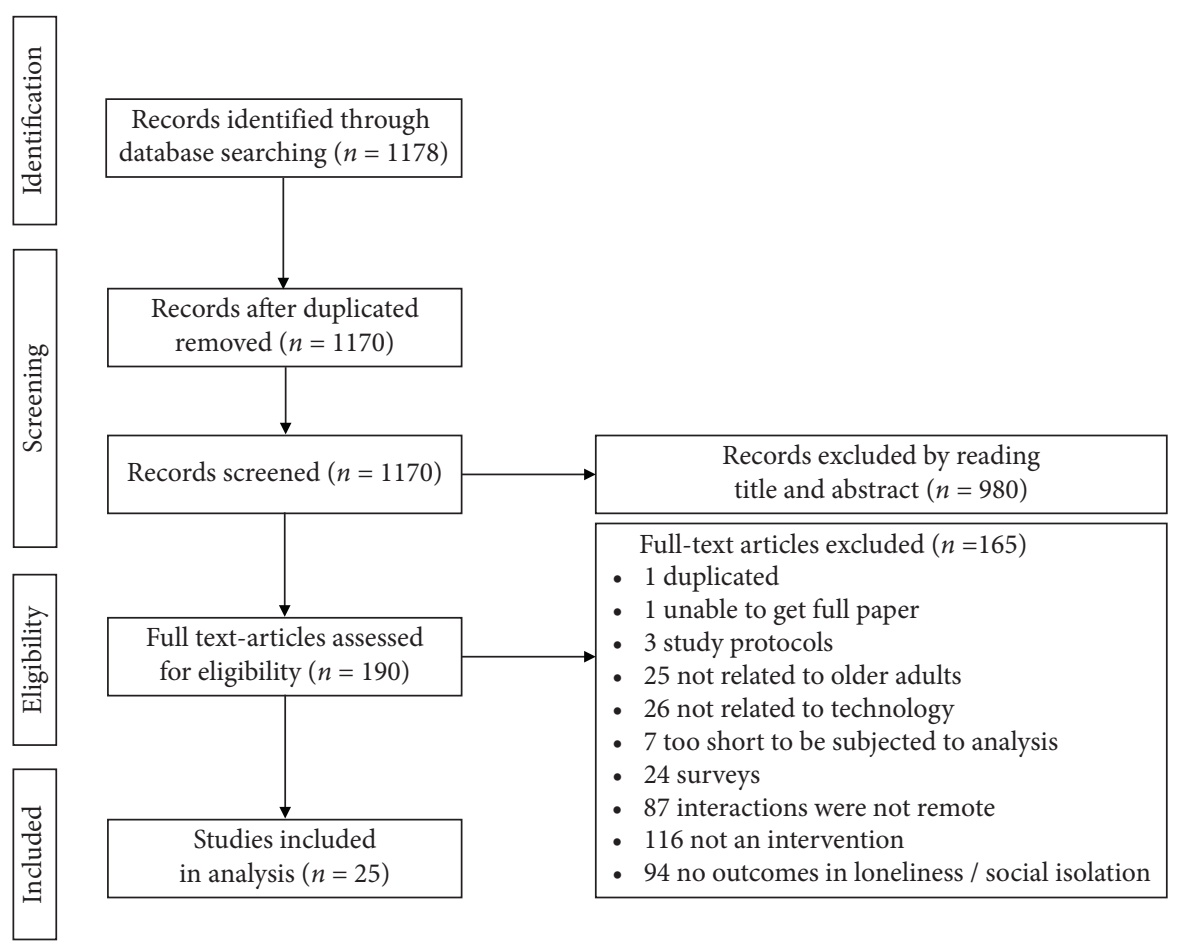

FIgURE 1: The full selection process, following the PRISMA statement guidelines.

used to meet new people online. For two studies [30, 31], we were able to contact and get a reply from the authors.

\section{Results}

3.1. Study Characteristics and Outcomes. We start by summarizing the interventions analyzed. There were 13 interventions that considered loneliness as a primary outcome [30-42], one of which also considered social isolation [34]. Another 12 had loneliness and/or social connectedness as secondary outcomes (see Table 1, Outcomes).

Six interventions conducted qualitative studies, relying on direct or indirect (e.g., reports by staff) observation, questionnaires, and interviews (see Table 1, Study methods). All qualitative studies had positive outcomes, reporting mainly a decrease in loneliness [30, 32, 40, 43] (see Table 1, Conclusion). We must note, however, that some interventions described their results as "perceptions" or "being anecdotal" [40], and not resulting from "standardized measurement tools" [32].

The other 19 interventions conducted quantitative studies, although only five were randomized controlled trials (RCTs) $[35,36,42,50,44]$ and one was a group randomized trial [33]. The remaining interventions all relied on standardized tools to measure loneliness or social isolation or some quantifiable variable such as the volume of incoming and outgoing interactions [36] or the size of the social network [47]. Seven studies reported no significant differences, but the majority reported positive outcomes such as decreased loneliness $(n=9)$ and increased network size ( $n=2$; see Table 1 , Conclusion).

All but two interventions had measured participants' conditions at baseline, indicating that being lonely or isolated was a requirement for inclusion but without reporting how this condition was determined [41, 43]. Two studies included participants that perceived themselves as lonely [30, 32], while most interventions measured baseline conditions with some form or variant of the UCLA $(n=13)$ or De Jong Gierveld ( $n=4)$ loneliness scales.

Finally, we mention the lack of agreement on the effectiveness of video chat and social networks. Széman [41] reported that Skype (video chat) helped to strengthen family ties and expand interpersonal connections, as well as to encourage learning on how to use other tools such as e-mail and chat. However, a computer training intervention by Blažun et al. [32] found that levels of loneliness for those who used Skype did not change, while those less lonely after the training used mainly e-mail, not Skype. Also, regarding social networking sites, Ballantyne et al. [30] reported a decrease in loneliness as a result of using a social network for older adults. These sites gave more control for users to manage their loneliness by giving access to contacts at any time and with no need to leave home. On the other hand, Széman [41] noted that Skype was preferred to Facebook because it was simpler to use even after participants had become familiar with Facebook and its functionalities. It is interesting to note that all the aforementioned interventions were supported by desktop/laptop computers and offered off-the-shelf solutions. No other conflicting results were found.

3.2. Challenges and Intervention Strategies. With respect to our first research question, we found that the lack of social relationships and infrequent contacts have been the most 
TABLE 1: Summary of the interventions analyzed.

\begin{tabular}{|c|c|c|c|c|c|c|}
\hline Intervention & $\begin{array}{c}\text { Technology/ } \\
\text { device }\end{array}$ & $\begin{array}{l}\text { Study }^{\mathrm{a}} \text { : length/ } \\
\text { participants/age }\end{array}$ & Strategies & $\begin{array}{c}\text { Study settings/ } \\
\text { methods }\end{array}$ & $\begin{array}{c}\text { Outcomes: primary/ } \\
\text { secondary }\end{array}$ & $\begin{array}{c}\text { Measurements } / \\
\text { Conclusion }\end{array}$ \\
\hline $\begin{array}{l}\text { Ballantyne } \\
\text { et al. [30] }\end{array}$ & $\begin{array}{l}\text { Social network } \\
\text { (About my } \\
\text { age)/computer }\end{array}$ & $\begin{array}{c}3 \text { months } / 4 / \\
69-85\end{array}$ & $\begin{array}{l}\text { Internet and } \\
\text { computer } \\
\text { training }\end{array}$ & $\begin{array}{l}\text { Home/pilot study, } \\
\text { prepost interviews }\end{array}$ & Loneliness & $\begin{array}{c}\text { Interview/decreased } \\
\text { loneliness }\end{array}$ \\
\hline $\begin{array}{l}\text { Blažun et al. } \\
{[32]}\end{array}$ & $\begin{array}{l}\text { E-mail, } \\
\text { Internet, and } \\
\text { Skype/ } \\
\text { computer }\end{array}$ & $\begin{array}{c}3 \text { weeks } / 45 / 66 \text { in } \\
\text { Finland, } 77 \text { in } \\
\text { Slovenia }\end{array}$ & $\begin{array}{l}\text { Internet and } \\
\text { computer } \\
\text { training }\end{array}$ & $\begin{array}{l}\text { Home in Finland, } \\
\text { residence in } \\
\text { Slovenia/prepost } \\
\text { test no control; no } \\
\text { standard tool for } \\
\text { assessment }\end{array}$ & $\begin{array}{l}\text { Loneliness, ICT } \\
\text { knowledge, and } \\
\text { experience }\end{array}$ & $\begin{array}{c}\text { Questionnaire/ } \\
\text { decreased loneliness }\end{array}$ \\
\hline $\begin{array}{l}\text { Cattan et al. } \\
{[43]}\end{array}$ & $\begin{array}{l}\text { Phone calls/ } \\
\text { telephone }\end{array}$ & $\begin{array}{l}>3 \text { months/34/ } \\
55-95\end{array}$ & $\begin{array}{l}\text { Familiar, simple } \\
\text { technology; } \\
\text { ensure } \\
\text { interactions }\end{array}$ & $\begin{array}{l}\text { Home/mixed } \\
\text { methods }\end{array}$ & $\begin{array}{l}\text { Health and wellbeing/ } \\
\text { loneliness }\end{array}$ & $\begin{array}{c}\text { Questionnaire and } \\
\text { interview/decreased } \\
\text { feelings of loneliness, } \\
\text { increased } \\
\text { socialization }\end{array}$ \\
\hline $\begin{array}{l}\text { Cotten et al. } \\
{[34]}\end{array}$ & $\begin{array}{l}\text { E-mail, } \\
\text { Internet, and } \\
\text { Facebook/ } \\
\text { computer }\end{array}$ & $\begin{array}{l}1-2 \text { weeks } / 205 \\
(79 ; 126) / 82.8\end{array}$ & $\begin{array}{l}\text { Internet and } \\
\text { computer } \\
\text { training }\end{array}$ & $\begin{array}{c}\text { Facility/cross } \\
\text { sectional analysis }\end{array}$ & $\begin{array}{c}\text { Loneliness and social } \\
\text { isolation/quantity and } \\
\text { quality of } \\
\text { communications }\end{array}$ & $\begin{array}{c}\text { Hughes 3-items LS } \\
\text { (UCLA-based) and } \\
\text { questionnaire/ } \\
\text { decreased loneliness, } \\
\text { not social isolation }\end{array}$ \\
\hline $\begin{array}{l}\text { Dodge et al. } \\
{[44]}\end{array}$ & $\begin{array}{l}\text { Video chat/ } \\
\text { touch-screen } \\
\text { computer }\end{array}$ & $\begin{array}{c}6 \text { weeks/83 }(41 ; \\
42) / 80.5\end{array}$ & $\begin{array}{l}\text { Familiar, simple } \\
\text { technology; } \\
\text { ensure } \\
\text { interactions; } \\
\text { provide } \\
\text { conversation } \\
\text { topics }\end{array}$ & $\begin{array}{c}\text { Facility/ } \\
\text { randomized } \\
\text { controlled trial }\end{array}$ & $\begin{array}{l}\text { Cognitive function/ } \\
\text { loneliness }\end{array}$ & $\begin{array}{l}\text { Hughes } 3 \text {-items LS } \\
\text { (UCLA-based)/no } \\
\text { difference }\end{array}$ \\
\hline $\begin{array}{l}\text { Fokkema } \\
\text { and } \\
\text { Knipscheer } \\
{[31]}\end{array}$ & $\begin{array}{l}\text { E-mail and } \\
\text { Internet/ } \\
\text { computer }\end{array}$ & $\begin{array}{c}3 \text { years } / 26(12 ; \\
14) / 66 \text { in } \\
\text { intervention, } 68 \\
\text { in control }\end{array}$ & $\begin{array}{l}\text { Internet and } \\
\text { computer } \\
\text { training }\end{array}$ & $\begin{array}{c}\text { Home/interrupted } \\
\text { time series, } \\
\text { nonequivalent } \\
\text { control group } \\
\text { prepost test } \\
\end{array}$ & Loneliness & $\begin{array}{c}\text { DeJong 11-items LS } \\
\text { and questionnaire/ } \\
\text { decreased loneliness }\end{array}$ \\
\hline $\begin{array}{l}\text { Garattini } \\
\text { et al. [45] }\end{array}$ & $\begin{array}{l}\text { Broadcast, } \\
\text { messages, and } \\
\text { calls/touch- } \\
\text { screen } \\
\text { computer- } \\
\text { phone hybrid }\end{array}$ & $\begin{array}{c}10 \text { weeks/19/ } \\
65-84\end{array}$ & $\begin{array}{c}\text { Familiar, simple } \\
\text { technology; } \\
\text { provide } \\
\text { conversation } \\
\text { topics }\end{array}$ & $\begin{array}{l}\text { Home/mixed } \\
\text { methods, } \\
\text { exploratory study }\end{array}$ & $\begin{array}{l}\text { Feasibility/social } \\
\text { connectedness }\end{array}$ & $\begin{array}{l}\text { DeJong 6-items LS, } \\
\text { log, interview, } \\
\text { questionnaire/helped } \\
\text { social connection } \\
\text { and created } \\
\text { interactions }\end{array}$ \\
\hline $\begin{array}{l}\text { Larsson et al. } \\
\text { [39] }\end{array}$ & $\begin{array}{c}\text { E-mail, } \\
\text { Internet, Skype, } \\
\text { and Facebook/ } \\
\text { computer }\end{array}$ & $\begin{array}{c}3 \text { months } / 30 / \\
61-89\end{array}$ & $\begin{array}{l}\text { Internet and } \\
\text { computer } \\
\text { training }\end{array}$ & $\begin{array}{l}\text { Home/randomized } \\
\text { crossover study }\end{array}$ & $\begin{array}{c}\text { Loneliness/satisfaction } \\
\text { with social contacts } \\
\text { online and offline }\end{array}$ & $\begin{array}{c}\text { UCLA LS/decreased } \\
\text { loneliness } \\
\text { (significant in both } \\
\text { groups); satisfaction } \\
\text { with social contacts } \\
\text { inconclusive }\end{array}$ \\
\hline $\begin{array}{l}\text { Machesney } \\
\text { et al. [40] }\end{array}$ & $\begin{array}{c}\text { Virtual } \\
\text { companion/ } \\
\text { tablet }\end{array}$ & 1 week/13/65-93 & $\begin{array}{c}\text { Familiar, simple } \\
\text { technology; } \\
\text { ensure } \\
\text { interactions } \\
\end{array}$ & $\begin{array}{l}\text { Home/one group } \\
\text { observational study }\end{array}$ & Loneliness & $\begin{array}{c}\text { UCLA LS/decreased } \\
\text { loneliness }\end{array}$ \\
\hline $\begin{array}{l}\text { Széman et al. } \\
{[41]}\end{array}$ & $\begin{array}{c}\text { E-mail, } \\
\text { Internet, Skype, } \\
\text { and Facebook/ } \\
\text { computer }\end{array}$ & $\begin{array}{l}>6 \text { months } / 15 \\
\text { (program), } 25 \\
\quad(\text { pilot }) />75\end{array}$ & $\begin{array}{l}\text { Internet and } \\
\text { computer } \\
\text { training }\end{array}$ & Home/case study & Loneliness & $\begin{array}{c}\text { Observation/ } \\
\text { increased size of } \\
\text { social network }\end{array}$ \\
\hline $\begin{array}{l}\text { White et al. } \\
{[42]}\end{array}$ & $\begin{array}{l}\text { E-mail, } \\
\text { Internet/ } \\
\text { computer }\end{array}$ & $\begin{array}{c}5 \text { months/93 ( } 48 ; \\
45) / 71 \text { in } \\
\text { interventions, } 72 \\
\text { in control }\end{array}$ & $\begin{array}{l}\text { Internet and } \\
\text { computer } \\
\text { training }\end{array}$ & $\begin{array}{c}\text { Facility/ } \\
\text { randomized } \\
\text { controlled trial }\end{array}$ & Loneliness & $\begin{array}{l}\text { UCLA LS (modified } \\
\text { anchors)/decreased } \\
\text { loneliness } \\
\text { (nonstatistically } \\
\text { significant) }\end{array}$ \\
\hline
\end{tabular}


TABle 1: Continued.

\begin{tabular}{|c|c|c|c|c|c|c|}
\hline Intervention & $\begin{array}{c}\text { Technology/ } \\
\text { device }\end{array}$ & $\begin{array}{l}\text { Study }{ }^{\mathrm{a}} \text { : length/ } \\
\text { participants/age }\end{array}$ & Strategies & $\begin{array}{l}\text { Study settings/ } \\
\text { methods }\end{array}$ & $\begin{array}{c}\text { Outcomes: primary/ } \\
\text { secondary }\end{array}$ & $\begin{array}{c}\text { Measurements } / \\
\text { Conclusion }\end{array}$ \\
\hline $\begin{array}{l}\text { Baez et al. } \\
{[46]}\end{array}$ & $\begin{array}{c}\text { Virtual } \\
\text { classroom, } \\
\text { messages, and } \\
\text { predefined } \\
\text { messages/tablet }\end{array}$ & $\begin{array}{c}10 \text { weeks/40 (20; } \\
20) / 71.5\end{array}$ & $\begin{array}{c}\text { Internet and } \\
\text { computer } \\
\text { training; } \\
\text { familiar, simple } \\
\text { technology; } \\
\text { ensure } \\
\text { interactions } \\
\end{array}$ & $\begin{array}{c}\text { Home/randomized } \\
\text { pilot trial }\end{array}$ & $\begin{array}{c}\text { Training adherence/ } \\
\text { loneliness and social } \\
\text { wellbeing }\end{array}$ & $\begin{array}{l}\text { Hughes } 3 \text {-items LS } \\
\text { (UCLA-based)/no } \\
\text { significant difference }\end{array}$ \\
\hline $\begin{array}{l}\text { Czaja et al. } \\
{[35]}\end{array}$ & $\begin{array}{c}\text { E-mail, } \\
\text { Internet, virtual } \\
\text { classroom, and } \\
\text { messages/ } \\
\text { computer }\end{array}$ & $\begin{array}{l}12 \text { months } / 300 \\
(150 ; 150) / 76.15\end{array}$ & $\begin{array}{l}\text { Internet and } \\
\text { computer } \\
\text { training; } \\
\text { familiar, simple } \\
\text { technology; } \\
\text { provide } \\
\text { conversation } \\
\text { topics }\end{array}$ & $\begin{array}{l}\text { Home/randomized } \\
\text { controlled trial }\end{array}$ & $\begin{array}{l}\text { Loneliness and social } \\
\text { isolation/attitude } \\
\text { towards technology } \\
\text { and proficiency }\end{array}$ & $\begin{array}{c}\text { Hawthorne } \\
\text { friendship scale, } \\
\text { Cohen perceived } \\
\text { social support scale, } \\
\text { Lubben social } \\
\text { network size, UCLA } \\
\text { LS v3/decreased } \\
\text { loneliness and social } \\
\text { isolation }\end{array}$ \\
\hline $\begin{array}{l}\text { Banbury } \\
\text { et al. [47] }\end{array}$ & Skype/tablet & 44 weeks/52/73.0 & $\begin{array}{c}\text { Familiar, simple } \\
\text { technology; } \\
\text { ensure } \\
\text { interactions; } \\
\text { provide } \\
\text { conversation } \\
\text { topics } \\
\end{array}$ & $\begin{array}{c}\text { Home/ } \\
\text { nonrandomized } \\
\text { noncontrolled } \\
\text { prepost test }\end{array}$ & $\begin{array}{l}\text { Educational goals/ } \\
\text { social support }\end{array}$ & $\begin{array}{l}\text { Social (egocentric) } \\
\text { network analysis } \\
\text { interviews, focus } \\
\text { groups/increased } \\
\text { network size }\end{array}$ \\
\hline $\begin{array}{l}\text { Barbosa et al. } \\
{[48]}\end{array}$ & $\begin{array}{c}\text { Messages } \\
\text { (video, photos, } \\
\text { audio, } \\
\text { predefined)/ } \\
\text { tablet }\end{array}$ & $\begin{array}{c}3 \text { months/12/ } \\
82.5\end{array}$ & $\begin{array}{l}\text { Familiar, simple } \\
\text { technology; } \\
\text { ensure } \\
\text { interactions }\end{array}$ & $\begin{array}{l}\text { Facility/feasibility } \\
\text { study }\end{array}$ & $\begin{array}{l}\text { Feasibility/social } \\
\text { connectedness }\end{array}$ & $\begin{array}{c}\text { Hughes 3-items LS } \\
\text { (UCLA-based), } \\
\text { Abbrev. Duke social } \\
\text { support index/ } \\
\text { increased social } \\
\text { interactions, high } \\
\text { perceived social } \\
\text { connectedness }\end{array}$ \\
\hline $\begin{array}{l}\text { Chiu and } \\
\mathrm{Wu}[33]\end{array}$ & $\begin{array}{c}\text { Line } \\
\text { (messaging } \\
\text { service), } \\
\text { YouTube/tablet }\end{array}$ & $\begin{array}{c}5 \text { months/54 (19; } \\
18 ; 17) / 73.0\end{array}$ & $\begin{array}{l}\text { Internet and } \\
\text { computer } \\
\text { training; } \\
\text { provide } \\
\text { conversation } \\
\text { topics }\end{array}$ & $\begin{array}{l}\text { Facility/group } \\
\text { randomized trial }\end{array}$ & $\begin{array}{l}\text { Cognitive, physical } \\
\text { functioning and } \\
\text { psychological } \\
\text { wellbeing/quality of } \\
\text { life }\end{array}$ & $\begin{array}{c}\text { CES-D Chinese } \\
\text { version, Taiwanese } \\
\text { inventory of social } \\
\text { supportive behavior/ } \\
\text { increased social } \\
\text { support and } \\
\text { satisfaction with } \\
\text { contacts }\end{array}$ \\
\hline $\begin{array}{l}\text { Gutierrez } \\
\text { et al. [36] }\end{array}$ & $\begin{array}{l}\text { Video chat, } \\
\text { messages, and } \\
\text { photos/tablet }\end{array}$ & 9 weeks/9/69-81 & $\begin{array}{c}\text { Familiar, simple } \\
\text { technology; } \\
\text { ensure } \\
\text { interactions }\end{array}$ & $\begin{array}{l}\text { Home/empirical in- } \\
\text { the-wild study }\end{array}$ & $\begin{array}{l}\text { Frequency of social } \\
\text { interactions }\end{array}$ & $\begin{array}{l}\text { One-way repeated } \\
\text { ANOVA/increased } \\
\text { social interactions }\end{array}$ \\
\hline $\begin{array}{l}\text { Isaacson } \\
\text { et al. [49] }\end{array}$ & $\begin{array}{l}\text { Virtual } \\
\text { classroom, } \\
\text { video chat, } \\
\text { photos/TV, } \\
\text { remote, and } \\
\text { webcam }\end{array}$ & $\begin{array}{c}4-5 \text { weeks } / 40 / \\
85.86\end{array}$ & $\begin{array}{l}\text { Familiar, simple } \\
\text { technology; } \\
\text { ensure } \\
\text { interactions }\end{array}$ & Home/pilot study & $\begin{array}{l}\text { Technology adoption/ } \\
\text { emotional wellbeing }\end{array}$ & $\begin{array}{c}\text { UCLA LS v3, Lubben } \\
\text { social network scale/ } \\
\text { decreased loneliness, } \\
\text { increased social } \\
\text { wellbeing and social } \\
\text { network size }\end{array}$ \\
\hline $\begin{array}{l}\text { Jarvis et al. } \\
\text { [37] }\end{array}$ & $\begin{array}{c}\text { WhatsApp } \\
\text { (messaging } \\
\text { service)/mobile } \\
\text { phone } \\
\text { (smartphone) }\end{array}$ & $\begin{array}{c}3 \text { months/29 (13; } \\
16) / 74.93\end{array}$ & $\begin{array}{l}\text { Internet and } \\
\text { computer } \\
\text { training; ensure } \\
\text { interactions }\end{array}$ & $\begin{array}{c}\text { Facility/ } \\
\text { randomized } \\
\text { controlled study }\end{array}$ & $\begin{array}{c}\text { Loneliness and social } \\
\text { cognition/use of } \\
\text { technology }\end{array}$ & $\begin{array}{c}\text { YSQ short form, } \\
\text { DeJong 6-items LS/ } \\
\text { decreased loneliness }\end{array}$ \\
\hline
\end{tabular}


TABLE 1: Continued.

\begin{tabular}{|c|c|c|c|c|c|c|}
\hline Intervention & $\begin{array}{c}\text { Technology/ } \\
\text { device }\end{array}$ & $\begin{array}{l}\text { Study }{ }^{\mathrm{a}} \text { : length/ } \\
\text { participants/age }\end{array}$ & Strategies & $\begin{array}{c}\text { Study settings/ } \\
\text { methods }\end{array}$ & $\begin{array}{c}\text { Outcomes: primary/ } \\
\text { secondary }\end{array}$ & $\begin{array}{c}\text { Measurements }{ }^{\mathrm{b}} / \\
\text { Conclusion }\end{array}$ \\
\hline $\begin{array}{l}\text { Jarvis et al. } \\
\text { [38] }\end{array}$ & $\begin{array}{l}\text { WhatsApp } \\
\text { (messaging } \\
\text { service)/mobile } \\
\text { phone (smart } \\
\text { phone) }\end{array}$ & $\begin{array}{c}3 \text { months/32 (15; } \\
17) / 70.42\end{array}$ & $\begin{array}{l}\text { Internet and } \\
\text { computer } \\
\text { training }\end{array}$ & $\begin{array}{c}\text { Facility/ } \\
\text { experimental } \\
\text { randomized } \\
\text { comparative study }\end{array}$ & Loneliness & $\begin{array}{l}\text { DeJong 6-items LS, } \\
\text { focus groups/ } \\
\text { decreased loneliness }\end{array}$ \\
\hline $\begin{array}{l}\text { Morton et al. } \\
\text { [50] }\end{array}$ & $\begin{array}{l}\text { E-mail, } \\
\text { Internet, } \\
\text { Facebook, and } \\
\text { Skype }\end{array}$ & $\begin{array}{c}4 \text { months/76 (44; } \\
32) / 80.71\end{array}$ & $\begin{array}{l}\text { Internet and } \\
\text { computer } \\
\text { training }\end{array}$ & $\begin{array}{l}\text { Some at home, } \\
\text { some at facility/ } \\
\text { randomized } \\
2 \times 2 \times 2 \text { study }\end{array}$ & $\begin{array}{l}\text { Cognitive and mental } \\
\text { health/social network } \\
\text { activity and } \\
\text { satisfaction, loneliness }\end{array}$ & $\begin{array}{c}\text { Social network } \\
\text { activity index, UCLA } \\
\text { LS v3/no difference } \\
\text { in loneliness, } \\
\text { increased social } \\
\text { network activity }\end{array}$ \\
\hline $\begin{array}{l}\text { Myhre et al. } \\
\text { [51] }\end{array}$ & Facebook & $\begin{array}{c}8 \text { weeks/41 }(14 ; \\
13 ; 14) / 80.0 \\
\text { Facebook, } 73.38 \\
\text { online diary, } \\
79.29 \text { Waiting } \\
\text { list }\end{array}$ & $\begin{array}{l}\text { Internet and } \\
\text { computer } \\
\text { training; ensure } \\
\text { interactions; }\end{array}$ & $\begin{array}{l}\text { Some at home, } \\
\text { some at facility/3- } \\
\text { arm study }\end{array}$ & $\begin{array}{c}\text { Neuropsychological } \\
\text { tests/social } \\
\text { engagement }\end{array}$ & $\begin{array}{l}\text { UCLA LS v3, MOS } \\
\text { social support } \\
\text { survey, Lubben social } \\
\text { network } 18 \text {-i scale/ } \\
\text { no significant } \\
\text { difference }\end{array}$ \\
\hline $\begin{array}{l}\text { Barbosa et al. } \\
{[52]}\end{array}$ & $\begin{array}{l}\text { Video chat, } \\
\text { photos, audio } \\
\text { recording, } \\
\text { predefined } \\
\text { messages }\end{array}$ & 2 months/5/87.2 & $\begin{array}{c}\text { Familiar, simple } \\
\text { technology }\end{array}$ & $\begin{array}{l}\text { Facility/embedded } \\
\text { case study }\end{array}$ & $\begin{array}{l}\text { Feasibility and } \\
\text { adoption/social } \\
\text { connectedness }\end{array}$ & $\begin{array}{l}\text { Hughes 3-items LS } \\
\text { (UCLA-based), } \\
\text { Abbrev. Duke social } \\
\text { support index/no } \\
\text { significant difference }\end{array}$ \\
\hline $\begin{array}{l}\text { Pauly et al. } \\
\text { [53] }\end{array}$ & $\begin{array}{c}\text { E-mail, } \\
\text { Internet, social } \\
\text { network, and } \\
\text { messages }\end{array}$ & $\begin{array}{c}>6 \text { months } / 92 / \\
67.7\end{array}$ & $\begin{array}{l}\text { Internet and } \\
\text { computer } \\
\text { training }\end{array}$ & $\begin{array}{l}\text { Home/prepost, } \\
\text { repeated measures } \\
\text { study }\end{array}$ & $\begin{array}{l}\text { Physical activity/ } \\
\text { loneliness and } \\
\text { executive functioning }\end{array}$ & $\begin{array}{c}\text { Self-reported } \\
\text { questionnaires, R- } \\
\text { UCLA LS/no } \\
\text { significant difference }\end{array}$ \\
\hline $\begin{array}{l}\text { Tomasino } \\
\text { et al. [54] }\end{array}$ & $\begin{array}{l}\text { Virtual } \\
\text { classroom and } \\
\text { messages }\end{array}$ & 8 weeks/47/69.6 & $\begin{array}{l}\text { Internet and } \\
\text { computer } \\
\text { training; ensure } \\
\text { interactions; } \\
\text { provide } \\
\text { conversation } \\
\text { topics }\end{array}$ & Home/pilot study & $\begin{array}{l}\text { Depression, tech use } \\
\text { and usability/social } \\
\text { support and isolation }\end{array}$ & $\begin{array}{c}\text { PROMIS social } \\
\text { isolation 6-i, social } \\
\text { Provisions scale/no } \\
\text { significant difference }\end{array}$ \\
\hline
\end{tabular}

aThe number of participants in controlled studies is shown in parentheses (intervention; control); participants' age is indicated as mean, age range, or as reported in the study. ${ }^{b}$ LS stands for Loneliness Scale.

commonly addressed challenges to overcome loneliness and social isolation. One prominent strategy has been to train older adults to use computers and Internet $(n=16)$ $[30-35,37-39,41,42,46,50,51,53]$, although few technologies built specifically for older adults implemented this strategy [35, 46, 54]. After an initial training period, older adults in these studies were left to put in practice the skills learned to get in touch with others, with the exception of a single intervention where participants received continuous training [39]. Another strategy has been to ensure that the participants had someone to interact with $(n=10)$. These would usually be health professionals responding or contacting participants with some frequency for checks or to facilitate the intervention $[37,46,47,54]$ or other participants such as relatives who agreed to contact and support older adults during the study period $[36,48]$. Other interventions had volunteers making phone calls [43], trained interviewers having video chat conversations [44], and trained helpers linked to a virtual companion [40]. One intervention ensured interactions by design, requesting participants to post and comment on Facebook daily [51].
Usability and acceptance of the technology by older adults were also challenges taken into account. Here, strategies have been to employ familiar devices, such as the telephone [43] or television [49]; devices that researchers regarded as more accessible and friendly, such as tablets $[36,40,46,48,52]$; or devices that researchers considered simple enough to require minimal $[35,47]$ to no training, such as touch-screen computers [44, 45]. Finally, some interventions specifically aimed at solving conversational problems, such as the lack of conversation topics. One strategy was to provide context with educational content in virtual groups or classrooms (e.g., about health), which allowed participants to discuss and share personal experiences $[35,45,47,49,54]$. An intervention reported that the shared experience provided topics of conversation for the less active participants [45]. Other interventions prepared conversation around topics such as the childhood and hobbies of participants [44] or implemented buddy systems based on common interests [35]. Although not designed as a part of the intervention, participants who received weekly phone calls [43] also reported shared interests as a way to 
break the ice as well as to establish a "meaningful reciprocal relationship" and mentioned the importance of knowing about others' lives and events and wanting to talk about ordinary, everyday topics. Pictures as prompt for conversation was also common, retrieving relatives' pictures from social media [36], using pictures during videochats [44], or enabling sharing with family and friends $[33,48,49,52]$.

3.3. Technology Supporting Interventions. In answer to our second research question, we found that Internet access was fundamental to support long-distance interactions in all interventions, except for the telephone befriending service [43]. On top of Internet, different combinations of technologies were incorporated, including general Internet use for interaction (e.g., discussions in forums) and e-mail ( $n=10$; see Table 2 , Technology), video chat $(n=10)$, social networks $(n=8)$, virtual spaces or classrooms with messaging capabilities $(n=5)$, messaging services $(n=3)$, virtual companions $(n=1)$, and phone calls $(n=1)$.

Off-the-shelf solutions were favored $(n=15$; see Table 2$)$, including the social networks Facebook and About my age (a social network for older adults), Skype (video chat), WhatsApp, and Line (messaging services), a landline telephone service, as well as standard applications to use e-mail and Internet. Tailored solutions, designed specifically for interventions $(n=10)$ include systems that facilitated virtual spaces and messaging capabilities [35, 45, 47, 49, 54], systems that enabled different interaction channels via simplified interfaces $[36,48,52]$, a custom video chat system that allowed calling by simply touching the screen [44], and a virtual companion controlled remotely by a trained helper [40].

Computers, along with the mouse and keyboard as input devices, were preferred for supporting interventions $(n=10$; see Table 2), closely followed by tablets $(n=9)$ which seem to be most popular among more recent studies. Other interventions employed mobile phones $(n=3)$, traditional telephones $(n=1)$, customized TV sets $(n=1)$, and touch-screen computers $(n=3)$, one of which had a telephone handset attached to the screen so that users could get calls as they would on a regular telephone [45].

While interventions clearly report on the technology and devices used, features and channels used for communication are less discussed. This information is useful to gain insight into participants' preferences and adoption, and it is usually reported in terms of "most used" features. Some interventions report that comments and likes are preferred over predetermined messages [54]; the latter are usually not used much $[46,48]$ although reported to be useful when starting to use systems [48]. Other interventions $[49,53]$ indicate that interaction features are used as much as content consumption features (e.g., messaging and reading news). Studies with more qualitative insights praised video chat for allowing users to see people on the other side, which was particularly important with grandchildren [41]. One intervention even delivered fully remote training using Skype [39]. Interventions also reported that participants used Internet and computers to reengage in old interests, explore content, or participate in online communities [30-32, 39, 41], sometimes achieving a notorious improvement, even allowing to overcome depression [41].

In terms of understanding the human factors in the interventions and the relation between users and technology, we found that all interventions required older adults to use the technology on their own, although some studies reported that assistance was necessary for a long period $[48,52]$. Aside for the telephone befriending service, all provided some kind of training or support (see Table 2, Training or support). Nonetheless, some interventions did require participants not to be proficient with technology on which they would receive training, for instance, having none to limited experience with social networks [51] or no computer experience [30-32, 39, 41]. Interestingly, two tablet-based interventions reported requiring no computer experience $[36,47]$. The remaining interventions did not required lack of experience to participate.

With respect to the difficulties in interacting with technology, White et al. [42] reported on computer users having problems with vision, colors on the screen, the mouse, and remembering how to use e-mail and Internet. Other computer users withdrew from their studies because learning how to use the computer was too difficult $[30,31]$ or they had found a better alternative [31]. In touch-screen computer interventions, participants reported difficulties to join into group conversations and limited privacy settings and amount of characters per message, as well as frustration on the disengagement of others [45]. The lack of participation of others is echoed by more recent studies, mentioning that relatives did not respond often due to using WhatsApp (not supported in the study) more than e-mail [52] and that not receiving responses could increase the perception of loneliness [48].

Tablet users reported feeling silly talking to a virtual pet, problems with audio, and delay in messages [40]. A number of studies also reported that reduced dexterity could lead to difficulties with texting and typing [33], with gestures such as tapping and swiping $[48,52]$, and coordination issues such as requiring to hold voice icon to record audio messages [37].

Usability, although not formally an outcome, was analyzed by some interventions. In a computer training course by Blažun et al. [32], which included e-mail, Internet, and Skype, participants self-reported on satisfaction $(64 \%$ were very satisfied or satisfied) and ease of use (74\% reported it was easy). On the other hand, some interventions using computers [32, 41] and tablets [40] reported initial feelings of uncertainty and fear regarding use and adoption of technology. These interventions also reported that such feelings were overcome in time, as participants gained confidence and familiarity, thanks to both training and use. One computer-supported study indicates that $80 \%$ of participants reported that it was easy to become skilled at using the system. Studies with touch-screen computers [50] and tablets $[48,52]$ also reported increased confidence. Tablet studies, in particular, reported positive results with ease of use of the system [53] or interface [48] albeit some adaptation time required for gestures [52]. 
TABLE 2: Technology used in interventions.

\begin{tabular}{|c|c|c|c|c|c|}
\hline Intervention & Technology & $\begin{array}{l}\text { Custom or } \\
\text { off-the-shelf }\end{array}$ & Devices & $\begin{array}{c}\text { Technology ownership/ } \\
\text { experience }\end{array}$ & Training or support \\
\hline $\begin{array}{l}\text { Ballantyne et al. } \\
{[30]}\end{array}$ & $\begin{array}{l}\text { Social network (About } \\
\text { my age) }\end{array}$ & $\begin{array}{l}\text { Off-the- } \\
\text { shelf }\end{array}$ & Computer & Nonproficiency required & $\begin{array}{l}\text { Initial training } \\
\text { sessions }\end{array}$ \\
\hline Blažun et al. [32] & $\begin{array}{l}\text { E-mail, Internet, and } \\
\text { Skype }\end{array}$ & $\begin{array}{l}\text { Off-the- } \\
\text { shelf }\end{array}$ & Computer & Nonproficiency required & $\begin{array}{l}\text { Initial training } \\
\text { sessions }\end{array}$ \\
\hline Cattan et al. [43] & Phone calls & $\begin{array}{l}\text { Off-the- } \\
\text { shelf }\end{array}$ & Telephone & $\mathrm{N} / \mathrm{A}$ & N/A \\
\hline Cotten et al. [34] & $\begin{array}{l}\text { E-mail, Internet, and } \\
\text { Facebook }\end{array}$ & $\begin{array}{l}\text { Off-the- } \\
\text { shelf }\end{array}$ & Computer & Did not report & $\begin{array}{l}\text { Initial training } \\
\text { sessions }\end{array}$ \\
\hline Dodge et al. [44] & Video chat & Custom & $\begin{array}{l}\text { Touch-screen } \\
\text { computer }\end{array}$ & No previous use of PC (15\%) & $\begin{array}{l}\text { Visits for setup; no } \\
\text { training }\end{array}$ \\
\hline $\begin{array}{l}\text { Fokkema and } \\
\text { Knipscheer [31] }\end{array}$ & E-mail and Internet & $\begin{array}{l}\text { Off-the- } \\
\text { shelf }\end{array}$ & Computer & Nonproficiency required & $\begin{array}{l}\text { Initial training } \\
\text { sessions }\end{array}$ \\
\hline $\begin{array}{l}\text { Garattini et al. } \\
{[45]}\end{array}$ & $\begin{array}{l}\text { Virtual room, calls, } \\
\text { messages, and } \\
\text { broadcasts }\end{array}$ & Custom & $\begin{array}{l}\text { Touch-screen } \\
\text { computer with } \\
\text { phone handset }\end{array}$ & No computer ownership (68\%) & $\begin{array}{l}\text { Visits for training } \\
\text { and support }\end{array}$ \\
\hline $\begin{array}{l}\text { Larsson et al. } \\
{[39]}\end{array}$ & $\begin{array}{l}\text { E-mail, Internet, } \\
\text { Facebook, and Skype }\end{array}$ & $\begin{array}{l}\text { Off-the- } \\
\text { shelf }\end{array}$ & Computer & $\begin{array}{l}\text { Computer ownership and } \\
\text { nonproficiency required }\end{array}$ & $\begin{array}{l}\text { Visits for training } \\
\text { and support; remote } \\
\text { training }\end{array}$ \\
\hline $\begin{array}{l}\text { Machesney et al. } \\
{[40]}\end{array}$ & $\begin{array}{c}\text { Virtual companion (pet } \\
\text { avatar) }\end{array}$ & Custom & Tablet & Did not report & $\begin{array}{l}\text { Continuous visits; } \\
\text { remote support }\end{array}$ \\
\hline $\begin{array}{l}\text { Széman et al. } \\
\text { [41] }\end{array}$ & $\begin{array}{c}\text { E-mail, Internet, } \\
\text { Facebook, and Skype }\end{array}$ & $\begin{array}{l}\text { Off-the- } \\
\text { shelf }\end{array}$ & Computer & Nonproficiency required & $\begin{array}{l}\text { Initial training } \\
\text { sessions }\end{array}$ \\
\hline White et al. [42] & E-mail and Internet & $\begin{array}{l}\text { Off-the- } \\
\text { shelf }\end{array}$ & Computer & $\begin{array}{c}\text { Owned a PC }(9 \%) \text {; no previous } \\
\text { experience }(60 \%)\end{array}$ & $\begin{array}{l}\text { Continuous visits; } \\
\text { remote support }\end{array}$ \\
\hline Baez et al. [46] & $\begin{array}{l}\text { Virtual classroom, } \\
\text { messages, and } \\
\text { predefined messages }\end{array}$ & Custom & Tablet & Did not report & $\begin{array}{l}\text { Initial training; } \\
\text { remote support }\end{array}$ \\
\hline Czaja et al. [35] & $\begin{array}{l}\text { E-mail, Internet, virtual } \\
\text { classroom, and messages }\end{array}$ & Custom & Computer & $\begin{array}{l}\text { Participants had minimal } \\
\text { computer or Internet use } \\
\text { experience }\end{array}$ & $\begin{array}{l}\text { Initial training; check } \\
\text { visits; remote support }\end{array}$ \\
\hline $\begin{array}{l}\text { Banbury et al. } \\
\text { [47] }\end{array}$ & Skype & $\begin{array}{l}\text { Off-the- } \\
\text { shelf }\end{array}$ & Tablet & $\begin{array}{l}\text { Most had no previous video } \\
\text { conference experience }\end{array}$ & Visit for setup \\
\hline $\begin{array}{l}\text { Barbosa et al. } \\
{[48]}\end{array}$ & $\begin{array}{l}\text { Messages (video, photos, } \\
\text { audio, and predefined) }\end{array}$ & Custom & Tablet & $\begin{array}{c}\text { Moderate (5), basic (3), or no } \\
\text { experience }(4)\end{array}$ & $\begin{array}{l}\text { Initial training; } \\
\text { weekly visits for } \\
\text { support }\end{array}$ \\
\hline $\begin{array}{l}\text { Chiu and Wu } \\
{[33]}\end{array}$ & $\begin{array}{c}\text { Line (messaging service) } \\
\text { and YouTube }\end{array}$ & $\begin{array}{l}\text { Off-the- } \\
\text { shelf }\end{array}$ & Tablet & $\begin{array}{l}\text { No computer learning } \\
\text { experience }(82 \%)\end{array}$ & $\begin{array}{l}\text { Training sessions } \\
\text { (long period) }\end{array}$ \\
\hline $\begin{array}{l}\text { Gutierrez et al. } \\
{[36]}\end{array}$ & $\begin{array}{l}\text { Video chat, messages, } \\
\text { and photos }\end{array}$ & Custom & Tablet & $\begin{array}{l}\text { First-time as computer user } \\
\text { required }\end{array}$ & $\begin{array}{c}\text { Provided by family } \\
\text { member }\end{array}$ \\
\hline $\begin{array}{l}\text { Isaacson et al. } \\
\text { [49] }\end{array}$ & $\begin{array}{l}\text { Virtual classroom, video } \\
\text { chat, and photos }\end{array}$ & Custom & $\begin{array}{l}\mathrm{TV}, \text { remote, and } \\
\text { webcam }\end{array}$ & $\begin{array}{l}\text { Many not proficient with smart } \\
\text { phones/computers }\end{array}$ & $\begin{array}{l}\text { Visit for setup and } \\
\text { training }\end{array}$ \\
\hline Jarvis et al. [37] & $\begin{array}{l}\text { WhatsApp (messaging } \\
\text { service) }\end{array}$ & $\begin{array}{l}\text { Off-the- } \\
\text { shelf }\end{array}$ & $\begin{array}{l}\text { Mobile phone } \\
\text { (smart phone) }\end{array}$ & $\begin{array}{c}\text { Used mobile to contact family } \\
\text { and friends (55\%), none had } \\
\text { used WhatsApp }\end{array}$ & $\begin{array}{l}\text { Initial training; } \\
\text { weekly visits for } \\
\text { support }\end{array}$ \\
\hline Jarvis et al. [38] & $\begin{array}{l}\text { WhatsApp (messaging } \\
\text { service) }\end{array}$ & $\begin{array}{l}\text { Off-the- } \\
\text { shelf }\end{array}$ & $\begin{array}{l}\text { Mobile phone } \\
\text { (smart phone) }\end{array}$ & 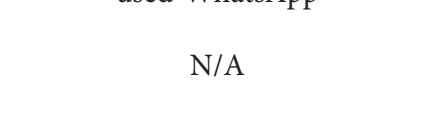 & $\begin{array}{l}\text { Initial training; } \\
\text { weekly visits for } \\
\text { support }\end{array}$ \\
\hline $\begin{array}{l}\text { Morton et al. } \\
{[50]}\end{array}$ & $\begin{array}{c}\text { E-mail, Internet, } \\
\text { Facebook, and Skype }\end{array}$ & $\begin{array}{l}\text { Off-the- } \\
\text { shelf }\end{array}$ & $\begin{array}{l}\text { Touch-screen } \\
\text { computer }\end{array}$ & $\begin{array}{l}\text { Required no current access to } \\
\text { Internet }\end{array}$ & $\begin{array}{l}\text { Continuous visits; } \\
\text { remote support }\end{array}$ \\
\hline Myhre et al. [51] & Facebook & $\begin{array}{l}\text { Off-the- } \\
\text { shelf }\end{array}$ & $\begin{array}{l}\text { Computer and } \\
\text { tablet }\end{array}$ & $\begin{array}{c}\text { No social network or minimal } \\
\text { use required, tablet/computer } \\
\text { ownership required }\end{array}$ & Initial training \\
\hline $\begin{array}{l}\text { Barbosa et al. } \\
{[52]}\end{array}$ & $\begin{array}{l}\text { Video chat, photos, } \\
\text { audio recording, and } \\
\text { predefined messages }\end{array}$ & Custom & Tablet & $\begin{array}{l}\text { All participants inexperienced } \\
\text { with tech, save one }\end{array}$ & $\begin{array}{l}\text { Initial training; } \\
\text { weekly visits for } \\
\text { support }\end{array}$ \\
\hline Pauly et al. [53] & $\begin{array}{l}\text { E-mail, Internet, social } \\
\text { network, and messages }\end{array}$ & $\begin{array}{l}\text { Off-the- } \\
\text { shelf }\end{array}$ & Tablet & $\begin{array}{c}\text { None or very little experience } \\
\text { with portable electronic devices } \\
(67 \%)\end{array}$ & $\begin{array}{l}\text { Initial training; } \\
\text { workshop during } \\
\text { intervention }\end{array}$ \\
\hline $\begin{array}{l}\text { Tomasino et al. } \\
{[54]}\end{array}$ & $\begin{array}{c}\text { Virtual classroom, } \\
\text { messages }\end{array}$ & Custom & $\begin{array}{l}\text { Computer, tablet, } \\
\text { mobile phones }\end{array}$ & $\begin{array}{c}\text { Required Internet access and } \\
\text { basic Internet skills }\end{array}$ & Remote support \\
\hline
\end{tabular}


3.4. Social Interaction and Contacts. In relation to our third research question, out of the 25 interventions, 20 involved online groups (see Table 3 ), while in the remaining five, participants could only contact one other person (one-toone interventions).

The majority of interventions $(n=19$; see Table 3 , Contacts) focused on interactions between older adults and their family and friends. Eight interventions had explicitly planned for contact with family and friends: Gutierrez et al. [36], Garattini et al. [45], and Neves et al. [48, 52] asked participants to choose relatives and friends to be added to their contact list, while Larsson et al. [39] had "searching for relatives" as a task on their program. The other three taught participants to communicate with family and friends via Internet [31, 34] or Skype [41].

Interestingly, Széman [41] reported that participants wanted to contact only their families in the beginning, but later asked to expand their network to include old friends, acquaintances, new people, and finally other participants. Initial apprehension to contact new people is also reported by [47]. Eleven interventions reported interactions between older adult study participants, with one even designed to "encourage social interaction among strangers" [45]. Among studies comparing frequency of contact, Fokkema and Knipscheer [31] reported that, out of 12 participants, ten had contact with family and acquaintances and three with other study participants. Baez et al. [46] report that group messages between participants was used more than one-to-one private messages, suggesting that more time might be needed before developing meaningful relationships.

One-to-one interventions limited contacts to family, friends, and acquaintances $[48,52]$, as well as trained interviewers [44], trained helpers [40], or volunteers [43], put in place for the interventions. However, interventions that included general Internet use and social networks allowed participants to meet new people. Larsson et al. [39] even had "finding a new friend with the same interests" as a program goal and contacting an unknown person through Internet as a task. Authors who replied to our inquiry on how new people were met said that most new contacts were other participants reached through forums [31] or that participants met others in social network pages about shared interests and during online activities offered by the site, such as "quiz night online" [30].

Intergenerational relationships were also indicated as important. Three computer training interventions explicitly mention interactions with young people. Blažun et al. [32] reported benefits for both parties, with younger volunteers teaching elders new ICT skills, and at the same time, learning by themselves from the life stories of the older adults. White et al. [42] reported that "some participants agreed to be e-mail pals with middle school students", and Széman [41] reported that opportunities to contact grandchildren was the "biggest motivation" for participants. Studies by Barbosa et al. $[48,52]$ also report that some participants were more engaged with their grandchildren, communicating with them especially, and being happy about having the chance to see them grow through video.
Interactions in person also occurred. Sometimes, participants met during the interventions and formed groups: a computer interest group [42] (which got to publish a newsletter for the community), group workshops [53] and training [37], and discussion and support groups [30], for example, to watch and discuss YouTube videos [33]. Three interventions included support or teaching imparted in person by relatives or volunteers $[32,36,41]$. Sometimes, participants also wanted to meet in person as a result of the interventions. Myhre et al. [51] reported that participants used Facebook to arrange faceto-face meetings, after forming and maintaining relationship during the study period. Banbury et al. [47] also reported that six participants met after talking via videoconference.

In addition, visits were made in order to provide assistance or to make sure that systems were working properly (see Table 3, Contact with research staff). Especially, in interventions that provided education for computer and Internet use, visits were more or less frequent after the training period [30-32, 34, 39, 41, 42]. Few interventions did not report visits to participants: one-to-one interventions including video chat with the trained interviewer [44] (one visit for setup only) and the telephone befriending service [43], as well as studies that relied on the family to support the older adults [36] or reported offering remote support throughout [54]. Since our focus is on loneliness and isolation, it is worth noting that, in a large part of the interventions, there were visits to participants, which may have had an effect on the results.

\section{Discussion}

In the following, we analyze the findings from our research questions. In terms of challenges addressed by interventions, the strategies applied, and the intervention outcomes (RQ1), we observed that most interventions have dealt with the lack of social relationships and infrequent contacts by training participants in the use of computers and Internet. While results have been positive, and it is true that training participants or providing simple technology might solve the digital divide, such strategies do not guarantee access to contacts or frequent interactions. We argue that it is important to address the barriers directly, targeting challenges with technology that incorporates strategies by design. Interventions providing simple technology also ensured interaction as a strategy, and most of these interventions have reported positive outcomes. More studies taking this strategy would contribute evidence allowing for comparison with studies that train participants. Also, some studies have tried to improve conversations, by providing some contextual information and conversation topics. This area seems promising, especially in light of the surge of artificial intelligence and conversational agents. As fully automated conversational agents were successful on interventions for young adults with symptoms of depression and anxiety [55], such agents could be designed to target loneliness and social isolation and adapted to help guide conversations and provide conversational cues. 
TABLE 3: Social interactions and contacts.

\begin{tabular}{|c|c|c|c|}
\hline Intervention & $\begin{array}{l}\text { Online group } \\
\text { or one-to-one }\end{array}$ & Contacts & Contact with research staff \\
\hline $\begin{array}{l}\text { Ballantyne et al. } \\
\text { [30] }\end{array}$ & Online group & Family and friends, new people & Weekly visits first, then fewer; phone calls at most $1 \mathrm{~h} /$ week \\
\hline Blažun et al. [32] & nline group & Family and friends, new people & Training once a week; $4 \mathrm{~h}$ in Finland and $3 \mathrm{~h}$ in Slovenia \\
\hline Cattan et al. [43] & One-to-one & & Variable number of $\mathrm{w}$ \\
\hline Cotten et al. [34] & Online group & Family and friends, new pe & Eight-week training (data from first 2 weeks) \\
\hline Dodge et al. [44] & One-to-one & Predefined (trained interviewers) & Video chat $30-35 \mathrm{~min} /$ day; 5 days/week \\
\hline $\begin{array}{l}\text { Fokkema and } \\
\text { Knipscheer }[41]\end{array}$ & Online group & $\begin{array}{l}\text { Family and friends, new people, } \\
\text { other participants, acquaintances }\end{array}$ & $5 \times 2$ h lessons; visits every $2-3$ weeks \\
\hline Garattini et al. [45] & Online group & $\begin{array}{l}\text { Family and friends, other } \\
\text { participants }\end{array}$ & $\begin{array}{c}4 \times 1 \mathrm{~h} \text { visits; messages via app; weekly calls (extra calls for } \\
\text { technical issues) }\end{array}$ \\
\hline Larsson et al. [39] & Online group & $\begin{array}{l}\text { Family and friends, } 1 \\
\text { and other partic }\end{array}$ & $\begin{array}{c}\text { Individual meeting offered weekly, group meeting every } 2 \\
\text { weeks }\end{array}$ \\
\hline $\begin{array}{l}\text { Machesney et al. } \\
{[40]}\end{array}$ & One-to-one & Predefined (trained helpers) & Visits and phone calls, available $24 / 7$ \\
\hline Széman et al. [41] & e group & $\begin{array}{l}\text { Family and friends, new people, } \\
\text { and acquaintances }\end{array}$ & $1 \times 1.5$ \\
\hline White et al. [42] & Online group & Family and friends, new people & $3 \times 2 \mathrm{~h}$ lessons, three $1 \mathrm{~h}$ lessons; trainer visits $2 \mathrm{~h} /$ week \\
\hline Baez et al. [46] & Online group & $\begin{array}{l}\text { Other participants, predefined } \\
\text { (coach) }\end{array}$ & $1.5 \mathrm{~h}$ training model before baseline; support messages/calls \\
\hline Czaja et al. [35] & Online group & $\begin{array}{r}\text { Family an } \\
\text { pa }\end{array}$ & Initial setup, $3 \mathrm{x}$ check visits, calls at week 1 , month \\
\hline Banbury et al. [47] & Online group & $\begin{array}{l}\text { Family and } \\
\text { (facilitator), ar }\end{array}$ & Minimol \\
\hline Barbosa et al. [48] & ne-to-one & Family and friends, a & Individual training \\
\hline$[33]$ & & Family and friends & 90-min ICT \\
\hline Gutierrez et al. [36] & oup & & Unaccounted frequency, support provided by family member \\
\hline Isaacs & oup & $\begin{array}{l}\text { Family and friends, other } \\
\text { participants }\end{array}$ & 1 secup anta \\
\hline Jarvis et al. [37] & Online group & $\begin{array}{l}\text { Family and friends, predefined } \\
\text { (facilitator) }\end{array}$ & $\begin{array}{r}8 \mathrm{x} 90 \text {-min training session }(\mathrm{c} \\
\text { supp }\end{array}$ \\
\hline Jarvis et al. [38] & Online group & $\begin{array}{l}\text { Family and friends, other } \\
\text { participants }\end{array}$ & $\begin{array}{l}\text { 2x 90-min training session/week over } 15 \text { days, then weekly } \\
\text { support visits }\end{array}$ \\
\hline Morton et al. [50] & Online group & $\begin{array}{l}\text { Family and friends, other } \\
\text { participants, and acquaintances }\end{array}$ & $\begin{array}{l}\text { 3x 90-min training/week (month } 1 \text { ); session every } 2 \text { weeks, } 1 \mathrm{~h} \\
\text { remote support alternate weeks (month 2), then } 1 \text { month of } \\
\text { remote support and no visits }\end{array}$ \\
\hline Myh & & & $3 \times 2$ \\
\hline Barbosa et al. [52] & One-to-one & Family and friends & $1 \mathrm{x}$ individual training session, then weekly visits \\
\hline Pauly et al. [53] & Online group & Family and friends & $\begin{array}{c}2 \mathrm{x} \text { training sessions before intervention, } 3 \mathrm{~h} \text { customized } \\
\text { workshop during intervention }\end{array}$ \\
\hline Tomasino & Online & $\begin{array}{l}\text { Other participants, predefined } \\
\text { (coach) }\end{array}$ & Remote support throughout \\
\hline
\end{tabular}

We also note that future studies should look into providing stronger evidence on the impact of the interventions conducted. Despite a majority of interventions reporting positive outcomes, and relying on quantitative methods, only five were RCTs. Studies disagree on the effectiveness of the technologies used (e.g., video chat and social networks), and some qualitative studies reports were obtained without standard measurement tools [32] or based on perceptions [40], making results hard to interpret and analyze. These findings are in line with previous reviews which have already highlighted weak methodologies [24] and noted that the quality of studies does not allow establishing conclusive remarks on effectiveness [25].

While we are advocating for more rigorous methodologies, we are not suggesting that qualitative outcomes should be abandoned in favor of quantitative ones. Qualitative studies are indeed useful to provide insight, especially on the motives behind behaviors. In this review, we have found studies reporting on the reasons for technologies not being adopted or reasons for people to interact more (or less) with others, uncovered through qualitative methods. In this sense, a methodological guide to designing studies in this area would greatly benefit researchers, especially those from the IT field, who might be less familiar with user studies with vulnerable subjects.

With respect to the technology used in interventions and how this technology was used by older adults (RQ2), we found that desktop/laptops make for a big part of the devices used to support interventions. Considering how commonplace long-distance interactions are nowadays and the 
availability of devices (e.g., mobile phones), we were surprised to find that studies based on desktop computers were so common, especially, since age-related limitations experienced by older adult computer users [56] might hinder the interactions enabled, thus leading to poor intervention outcomes. However, we have spotted a trend in recent studies to favor tablets, and there are a few studies based on mobile and smart phones.

We also found less solutions designed specifically for older adults than studies relying on off-the-shelf technologies. This might be due to the higher investment that designing tailored technologies requires. Nonetheless, previous research shows that tailored tools could increase adoption [57] while more general solutions (e.g., Facebook) could pose challenges for older adults [58] and present asymmetries in the interactions (especially for intergenerational communications [59]). This presents a great opportunity for human computer interaction researchers to collaborate with technology-supported interventions to facilitate long-distance interactions for older adults.

The prevailing technologies were e-mail and general Internet use for interaction (e.g., discussions in forums), closely followed by social networks and video chat. We must note, however, that while we have identified some studies using more recent technologies such as messaging services (e.g., WhatsApp) that allow for picture sharing and reaching relatives more conveniently, we still observe a disconnect between the latest technologies available and those used to conduct formal studies.

Many interventions enabled a combination of features and channels for interaction; however, few reported on how and how frequently these were used. Since such reports are scant, we cannot assess technology adoption or effectiveness. Therefore, we recommend future interventions to add formal reports on usability (e.g., the System Usability Scale [60]) and to quantify features and interaction channels used by participants. The adoption of technology by older adults largely depends on learnability and perceived difficulty of use [61]. Using standard instruments to measure usability is key to explain the success of technology-supported interventions, while failing to address usability might raise concerns about the validity of the intervention.

Finally, with respect to the social interactions enabled (RQ3), we found that most interventions enabled interaction with online groups, rather than with one person put in place specifically for the intervention. Family and friends were the contact group reported by a majority of the interventions, some highlighting intergenerational relationships as particularly important for older adults. Nonetheless, here, we also lack quantitative information on the frequency of contact. Since all interventions with online groups included at least two different groups of people (e.g., family and friends and other participants), we cannot tell whether older adults prefer to contact certain groups nor assess the impact the type of relationship has on the effectiveness of interventions. Friendship relationships, for instance, have been associated with stronger effects for subjective wellbeing [62] as compared with familial relationships.

The need for quantitative information also applies to the channels used to interact with people from particular groups. For example, Széman [41] reports that older adults enjoyed seeing their grandchildren through video chat. Future studies should consider analyzing the impact on effectiveness of the contacts enabled and the channels used for interactions, as well as quantifying interactions and the contacts reached. This would allow to better understand the motivations and opportunities that exist for conversation between older adults and others.

Furthermore, despite assessing the effect of long-distance interactions, many studies reported interactions in person during the intervention (e.g., with other participants, with researchers). If interactions were frequent, the effect on intervention outcomes should be considered.

\section{Conclusions}

For interventions, technology had the fundamental role of enabling long-distance interactions and was used for support in different ways. By facilitating more channels for interaction and providing access to larger audiences, it allowed participants to expand social networks, strengthen existing ties, providing social support, or build community rapport. However, since existing interventions are few, they tell us about the feasibility of using technology for longdistance interactions, but it is still unclear how technology is actually used, what limitations and opportunities exist, and how these affect the success of the intervention.

Therefore, we highlight some recommendations for researchers approaching this field of study. First, on the study methods, it is important to (1) design studies as RCTs, (2) leverage standard instruments for measuring loneliness and social isolation, and (3) consider the potential impact of continued (and in person) contact with participants on measurements. This may seem obvious, but we found few studies with these characteristics. We also recommend to report and discuss separately the results for each interaction channel and by the type of relationship (e.g., with friends, children, and grandchildren), since without this information, it is hard to infer what worked. Second, in terms of challenges, open opportunities lie in studying how technologies can facilitate and improve conversation (e.g., by presenting shared interests as topics), as opposed to enabling them. Finally, a vast majority of current research has focused on training for using a specific technology. To date, little attention has been paid to (1) designing interventions that enable or encourage usage of technology in specific ways (e.g., organizing and encouraging access to chat rooms with specific topics) and on (2) using persuasive technologies that introduce motivational elements and help users initiate and sustain conversations on shared interests. We feel that addressing these gaps in current research can lead to a better understanding of the role technology can play in tackling loneliness, helping to alleviate one of the modern ailments of our society.

\section{Disclosure}

Part of this work has been included and published as part of the doctoral dissertation entitled "The Connective Power of 
Reminiscence: Designing a Reminiscence-based Tool to Increase Social Interactions in Residential Care" [63].

\section{Conflicts of Interest}

The authors declare that there are no conflicts of interest regarding the publication of this paper.

\section{Acknowledgments}

This work was supported by the Russian Science Foundation (project no. 19-18-00282). The authors would like to express their gratitude to the authors of the papers listed in this review who replied to their inquiry for further details. Their help has made this review work more thorough.

\section{References}

[1] L. F. Berkman and S. L. Syme, "Social networks, host resistance, and mortality: a nine-year follow-up study of alameda county residents," American Journal of Epidemiology, vol. 109, no. 2, pp. 186-204, 1979.

[2] T. E. Seeman, L. F. Berkman, D. Blazer, and J. W. Rowe, "Social ties and support and neuroendocrine function: the MacArthur studies of successful aging," Annals of Behavioral Medicine, vol. 16, no. 2, pp. 95-106, 1994.

[3] J. C. Barefoot, M. Grønbæk, G. Jensen, P. Schnohr, and E. Prescott, "Social network diversity and risks of ischemic heart disease and total mortality: findings from the Copenhagen city heart study," American Journal of Epidemiology, vol. 161, no. 10, pp. 960-967, 2005.

[4] B. H. Brummett, J. C. Barefoot, I. C. Siegler et al., "Characteristics of socially isolated patients with coronary artery disease who are at elevated risk for mortality," Psychosomatic Medicine, vol. 63, no. 2, pp. 267-272, 2001.

[5] E. Y. Cornwell and L. J. Waite, "Social disconnectedness, perceived isolation, and health among older adults," Journal of Health and Social Behavior, vol. 50, no. 1, pp. 31-48, 2009.

[6] L. Fratiglioni, H.-X. Wang, K. Ericsson, M. Maytan, and B. Winblad, "Influence of social network on occurrence of dementia: a community-based longitudinal study," The Lancet, vol. 355, no. 9212, pp. 1315-1319, 2000.

[7] J. T. Cacioppo, M. E. Hughes, L. J. Waite, L. C. Hawkley, and R. A. Thisted, "Loneliness as a specific risk factor for depressive symptoms: cross-sectional and longitudinal analyses," Psychology and Aging, vol. 21, no. 1, pp. 140-151, 2006.

[8] C. M. Perissinotto, I. Stijacic Cenzer, and E. C. Kenneth, "Loneliness in older persons: a predictor of functional decline and death," Archives of Internal Medicine, vol. 172, no. 14, pp. 1078-1084, 2012.

[9] J. Holt-Lunstad, T. B. Smith, M. Baker, T. Harris, and D. Stephenson, "Loneliness and social isolation as risk factors for mortality," Perspectives on Psychological Science, vol. 10, no. 2, pp. 227-237, 2015.

[10] J. de Jong Gierveld, T. van Tilburg, and P. A. Dykstra, "Loneliness and social isolation," Cambridge Handbooks in Psychology, pp. 485-500, Cambridge University Press, Cambridge, UK, 2006.

[11] P. A. Dykstra, "Older adult loneliness: myths and realities," European Journal of Ageing, vol. 6, no. 2, pp. 91-100, 2009.

[12] L. A. Theeke, "Predictors of loneliness in U.S. adults over age sixty-five," Archives of Psychiatric Nursing, vol. 23, no. 5, pp. 387-396, 2009.
[13] C. Wilson and B. Moulton, Loneliness Among Older Adults: A National Survey of Adults 45+, AARP, Washington, DC, USA, 2010.

[14] K. Yang and C. R. Victor, "The prevalence of and risk factors for loneliness among older people in China," Ageing and Society, vol. 28, no. 3, pp. 305-327, 2008.

[15] M. Baez, R. Nielek, F. Casati, and A. Wierzbicki, "Technologies for promoting social participation in later life," in Ageing and Digital Technology, pp. 285-306, Springer, Singapore, 2019.

[16] M. Pinquart and S. Sorensen, "Influences on loneliness in older adults: a meta-analysis," Basic and Applied Social Psychology, vol. 23, no. 4, pp. 245-266, 2001.

[17] B. Havens, M. Hall, G. Sylvestre, and T. Jivan, "Social isolation and loneliness: differences between older rural and urban Manitobans," Canadian Journal on Aging, vol. 23, no. 2, pp. 129-140, 2004.

[18] A. Williams and J. F. Nussbaum, Intergenerational Communication Across the Life Span, Routledge, Mahwah, NJ, USA, 2001.

[19] M.-C. Lin, J. Harwood, and J. L. Bonnesen, "Conversation topics and communication satisfaction in grandparentgrandchild relationships," Journal of Language and Social Psychology, vol. 21, no. 3, pp. 302-323, 2002.

[20] G. C. Wenger, R. Davies, S. Shahtahmasebi, and A. Scott, "Social isolation and loneliness in old age: review and model refinement," Ageing and Society, vol. 16, no. 3, pp. 333-358, 1996.

[21] P. DiMaggio, E. Hargittai, W. R. Neuman, and J. P. Robinson, "Social implications of the Internet," Annual Review of Sociology, vol. 27, no. 1, pp. 307-336, 2001.

[22] C. Haythornthwaite, "Social networks and internet connectivity effects," Information, Communication \& Society, vol. 8, no. 2, pp. 125-147, 2005.

[23] M. Choi, S. Kong, and D. Jung, "Computer and internet interventions for loneliness and depression in older adults: a meta-analysis," Healthcare Informatics Research, vol. 18, no. 3, pp. 191-198, 2012.

[24] P. Khosravi and A. H. Ghapanchi, "Investigating the effectiveness of technologies applied to assist seniors: a systematic literature review," International Journal of Medical Informatics, vol. 85, no. 1, pp. 17-26, 2016.

[25] Y.-R. R. Chen and P. J. Schulz, "The effect of information communication technology interventions on reducing social isolation in the elderly: a systematic review," Journal of Medical Internet Research, vol. 18, no. 1, p. e18, 2016.

[26] M. J. Grant and A. Booth, "A typology of reviews: an analysis of 14 review types and associated methodologies," Health Information \& Libraries Journal, vol. 26, no. 2, pp. 91-108, 2009.

[27] D. Moher, A. Liberati, J. Tetzlaff, D. G. Altman, and T. P. Group, "Preferred reporting items for systematic reviews and meta-analyses: the Prisma statement," PLoS Medicine, vol. 6, no. 7, pp. 1-6, 2009.

[28] World Health Organization, Definition of an Older or Elderly Person: Proposed Working Definition of an Older Person in Africa for the MDS Project, WHO, Geneva, Switzerland, 2002, http://www.who.int/healthinfo/survey/ageingdefnolder/en/.

[29] D. T. van Bel, K. C. H. J. Smolders, W. A. IJsselsteijn, and Y. de Kort, "Social connectedness: concept and measurement," in Proceedings of the 5th International Conference on Intelligent Environments, Barcelona, Spain, 2009.

[30] A. Ballantyne, L. Trenwith, S. Zubrinich, and M. Corlis, “"I feel less lonely": what older people say about participating in a social networking website," Quality in Ageing and Older Adults, vol. 11, no. 3, pp. 25-35, 2010. 
[31] T. Fokkema and K. Knipscheer, "Escape loneliness by going digital: a quantitative and qualitative evaluation of a Dutch experiment in using ECT to overcome loneliness among older adults," Aging \& Mental Health, vol. 11, no. 5, pp. 496-504, 2007.

[32] H. Blažun, K. Saranto, and S. Rissanen, "Impact of computer training courses on reduction of loneliness of older people in Finland and Slovenia," Computers in Human Behavior, vol. 28, no. 4, pp. 1202-1212, 2012.

[33] C.-J. Chiu and C. H. Wu, "Information and communications technology as a health promotion method for older adults in assisted-living facilities: three-arm group-randomized trial," JMIR Aging, vol. 2, Article ID e12633, 2019.

[34] S. R. Cotten, W. A. Anderson, and B. M. McCullough, "Impact of internet use on loneliness and contact with others among older adults: cross-sectional analysis," Journal of Medical Internet Research, vol. 15, no. 2, p. e39, 2013.

[35] S. J. Czaja, W. R. Boot, N. Charness, W. A. Rogers, and J. Sharit, "Improving social support for older adults through technology: findings from the PRISM randomized controlled trial," The Gerontologist, vol. 58, no. 3, pp. 467-477, 2018.

[36] F. J. Gutierrez, S. F. Ochoa, and J. Vassileva, "Mediating intergenerational family communication with computersupported domestic technology," in Proceedings of the CYTED-RITOS International Workshop on Groupware, Springer, Cham, Switzerland, 2017.

[37] M. A. Jarvis, A. Padmanabhanunni, and J. Chipps, "An evaluation of a low-intensity cognitive behavioral therapy mHealth-supported intervention to reduce loneliness in older people," International Journal of Environmental Research and Public Health, vol. 16, no. 7, p. 1305, 2019.

[38] M. A. Jarvis, J. Chipps, and A. Padmanabhanunni, “"This phone saved my life": older persons' experiences and appraisals of an mHealth intervention aimed at addressing loneliness," Journal of Psychology in Africa, vol. 29, no. 2, pp. 159-166, 2019.

[39] E. Larsson, M. Padyab, M. Larsson-Lund, and I. Nilsson, "Effects of a social Internet-based intervention programme for older adults: an explorative randomised crossover study," British Journal of Occupational Therapy, vol. 79, no. 10, pp. 629-636, 2016.

[40] D. Machesney, S. S. Wexler, T. Chen, and J. F. Coppola, "Gerontechnology companion: virtual pets for dementia patients," in Proceedings of the IEEE Long Island Systems, Applications and Technology (LISAT) Conference 2014, pp. 1-3, Farmingdale, NY, USA, May 2014.

[41] Z. Széman, "A new pattern in long term care in Hungary: Skype and youth volunteers," Anthropological Notebooks, vol. 20, pp. 105-117, 2014.

[42] H. White, E. McConnell, E. Clipp et al., "A randomized controlled trial of the psychosocial impact of providing Internet training and access to older adults," Aging \& Mental Health, vol. 6, no. 3, pp. 213-221, 2002.

[43] M. Cattan, N. Kime, and A.-M. Bagnall, "The use of telephone befriending in low level support for socially isolated older people-an evaluation," Health \& Social Care in the Community, vol. 19, no. 2, pp. 198-206, 2011.

[44] H. H. Dodge, J. Zhu, N. C. Mattek et al., "Web-enabled conversational interactions as a method to improve cognitive functions: results of a 6-week randomized controlled trial," Alzheimer's \& Dementia: Translational Research \& Clinical Interventions, vol. 1, no. 1, pp. 1-12, 2015.

[45] C. Garattini, J. Wherton, and D. Prendergast, "Linking the lonely: an exploration of a communication technology designed to support social interaction among older adults," Universal Access in the Information Society, vol. 11, no. 2, pp. 211-222, 2012.

[46] M. Baez, I. K. Far, F. Ibarra, M. Ferron, D. Didino, and F. Casati, "Effects of online group exercises for older adults on physical, psychological and social wellbeing: a randomized pilot trial," PeerJ, vol. 5, p. e3150, 2017.

[47] A. Banbury, D. Chamberlain, S. Nancarrow, J. Dart, L. Gray, and L. Parkinson, "Can videoconferencing affect older people's engagement and perception of their social support in long-term conditions management: a social network analysis from the Telehealth Literacy Project," Health \& Social Care in the Community, vol. 25, no. 3, pp. 938-950, 2017.

[48] B. B. Neves, R. Franz, R. Judges, C. Beermann, and R. Baecker, "Can digital technology enhance social connectedness among older adults? A feasibility study," Journal of Applied Gerontology, vol. 38, no. 1, pp. 49-72, 2019.

[49] M. Isaacson, I. Cohen, and C. N. Shpigelman, "Leveraging emotional wellbeing and social engagement of the oldest old by using advanced communication technologies: a pilot study using Uniper-Care's technology," in Proceedings of the 3rd IET International Conference on Technologies for Active and Assisted Living (TechAAL 2019), p. 5, London, UK, March 2019.

[50] T. A. Morton, N. Wilson, C. Haslam, M. Birney, R. Kingston, and L.-G. McCloskey, "Activating and guiding the engagement of seniors with online social networking: experimental findings from the AGES 2.0 project," Journal of Aging and Health, vol. 30, no. 1, pp. 27-51, 2018.

[51] J. W. Myhre, M. R. Mehl, and E. L. Glisky, "Cognitive benefits of online social networking for healthy older adults," The Journals of Gerontology: Series B, vol. 72, no. 5, pp. 752-760, 2017.

[52] B. B. Neves, R. L. Franz, C. Munteanu, and R. Baecker, "Adoption and feasibility of a communication app to enhance social connectedness amongst frail institutionalized oldest old: an embedded case study," Information, Communication \& Society, vol. 21, no. 11, pp. 1681-1699, 2018.

[53] T. Pauly, J. C. Lay, P. Kozik, P. Graf, A. Mahmood, and C. A. Hoppmann, "Technology, physical activity, loneliness, and cognitive functioning in old age," GeroPsych, vol. 32, no. 3, pp. 111-123, 2019.

[54] K. N. Tomasino, E. G. Lattie, J. Ho, H. L. Palac, S. M. Kaiser, and D. C. Mohr, "Harnessing peer support in an online intervention for older adults with depression," The American Journal of Geriatric Psychiatry, vol. 25, no. 10, pp. 1109-1119, 2017.

[55] K. K. Fitzpatrick, A. Darcy, and M. Vierhile, "Delivering cognitive behavior therapy to young adults with symptoms of depression and anxiety using a fully automated conversational agent (Woebot): a randomized controlled trial," JMIR Mental Health, vol. 4, no. 2, p. e19, 2017.

[56] C. B. Mayhorn, A. J. Stronge, A. C. McLaughlin, and W. A. Rogers, "Older adults, computer training, and the systems approach: a formula for success," Educational Gerontology, vol. 30, no. 3, pp. 185-203, 2004.

[57] K. Boyd, C. Nugent, M. Donnelly et al., "Easisocial: an innovative way of increasing adoption of social media in older people," in Smart Homes and Health Telematics, C. Bodine, S. Helal, T. Gu, and M. Mokhtari, Eds., pp. 21-28, Springer International Publishing, Cham, Switzerland, 2015.

[58] J. Coelho and C. Duarte, "Socially networked or isolated? differentiating older adults and the role of tablets and television," in In Human-Computer Interaction-INTERACT 
2015, J. Abascal, S. Barbosa, M. Fetter et al., Eds., pp. 129-146, Springer International Publishing, Cham, Switzerland, 2015.

[59] F. J. Gutierrez, S. F. Ochoa, and J. Vassileva, "Mediating asymmetries in family communication: supporting the eInclusion of older adults," in In Universal Access in HumanComputer Interaction, M. Antona and C. Stephanidis, Eds., pp. 438-448, Springer International Publishing, Cham, Switzerland, 2015.

[60] J. Brooke, "SUS-a quick and dirty usability scale," Usability Evaluation in Industry, vol. 189, p. 194, 1996.

[61] Y. Barnard, M. D. Bradley, F. Hodgson, and A. D. Lloyd, "Learning to use new technologies by older adults: perceived difficulties, experimentation behaviour and usability," Computers in Human Behavior, vol. 29, no. 4, pp. 1715-1724, 2013.

[62] M. Pinquart and S. Sörensen, "Influences of socioeconomic status, social network, and competence on subjective wellbeing in later life: a meta-analysis," Psychology and Aging, vol. 15, no. 2, pp. 187-224, 2000.

[63] F. Ibarra, The connective power of reminiscence-designing a reminiscence-based tool to increase social interactions in residential care, University of Trento, Trento, Italy, Ph.D. dissertation, 2018. 